\title{
Perforin Deficiency and Familial Hemophagocytic Lymphohistiocytosis
}

A review of: Stepp SE, Dufourcq-Lagelouse R, Le Deist F. Bhawan S, Certain S, Mathew PA, Henter J-I, Bennett M, Fischer A, de Saint Basile G, Kumar V 1999 Perforin gene defects in familial hemophagocytic lymphohistiocytosis. Science 286:1957-1959

$\mathrm{H}^{\mathrm{e}}$ emophagocytic lymphohistiocytosis (HLH) occurs in immunosuppressed subjects, in patients with malignant diseases and in patients with a recessively inherited disorder referred to as familial hemophagocytic lymphohistiocytosis (FHL).

HLH is characterized by fever, hepatosplenomegaly, cytopenias, hypertriglyceridemia, hypofibrinogenemia and evidence in a variety of tissues (especially bone marrow and liver) of ingestion of blood cells (especially erythrocytes) by histiocytes (i.e. hemophagocytosis)

In the non-familial forms, the etiology of HLH infections is usually viral, commonly Epstein-Barr virus. Viral infections also appear to be the precipitating event in FHL. There is evidence in each of the forms of HLH that there is an underlying immune defect predisposing the patient to overwhelming infection. In FHL, T cell and NK cell functions are defective (1).

Perforin is contained in the granules of cytotoxic $\mathrm{T}$ lymphocytes and its secretion contributes to T cell destruction of target cells. Perforin knock-out mice, although normal in appearance, when infected with lymphocytic choriomeningitis virus, develop a progressive infection (2), including evidence of severe cytopenia (3). Genetic studies of some families with FHL mapped the putative gene to chromosome 10q22. The perforin gene has been mapped to this chromosomal site. Therefore, it was reasonable to search for abnormalities in this gene in cases

\section{Alvin Zipursky}

of FHL. Stepp et al. (4) described their studies which have resulted in establishing that a genetic defect of perforin is the cause of FHL. They first established that perforin was actually located in the 10q22 site. They then studied eight patients in which the genetic defect had been mapped to chromosome 10q22. In all cases they found mutations in both copies of the perforin gene, including nonsense, frame shift or stop codons. The parents who were studied were heterozygous for the abnormal genes.

It is clear, therefore, that in these cases FHL was associated with a genetic mutation of perforin. They then determined that the $\mathrm{T}$ cells and NK cells of these patients were functionally deficient in in vitro assays of function. Finally they established that the abnormal genes led to an absolute deficiency of perforin in the lymphocytes of these patients.

It would appear therefore that in these cases, FHL is a disease due to a genetic abnormality which predisposes the child to overwhelming infection, usually viral. The disease is fatal without treatment. To date the only permanent cure for the disease is bone marrow transplantation, which replaces perforin-deficient lymphocytes with normal cells. It is also clear that not all cases of FHL are due to perforin deficiency because family studies have shown that in some patients the genetic abnormality is mapped to chromosome 9q21.3-22 or to another site (5). It is likely, however, that these genes are required for normal lymphocyte function and that mutations in them predispose subjects to lethal FHL.

These exciting findings indicate that HLH results from abnormalities of lymphocyte function either genetically determined (FHL) or the result of immune suppression. Of course it is likely that some of the sporadic cases represent genetic defects that have not yet been diagnosed.

1. Henter J-H, Arico, Elinder G, Imashuku S, Janka G 1998 Familial hemophagocytic lymphohistiocytosis. Primary hemophagocytic lymphohistiocytosis. Hematol Oncol Clin N Am 12:417-433

2. Walsh CM, Matloubian M, Liu C, Ueda R, Kurahara CG, Christensen JL, Huang MTF, Young JD, Ahmed R, Clark WR 1994 Immune function in mice lacking the perforin gene. Proc Natl Acad Sci USA 91:10854-10858

3. Binder D, van den Broek MF, Kägi D, Bluethmann H, Fehr J, Hengartner H, Zinkernagel RM 1998 Aplastic anemia rescued by exhaustion of cytokinesecreting CD8 + T cells in persistent infection with lymphocytic choriomeningitis virus. J Exp Med 187:1903-1920

4. Stepp SE, Dufourcq-Lagelouse R, Le Deist F, Bhawan S, Certain S, Mathew PA, Henter J-I, Bennett M, Fischer A, de Saint Basile G, Kumar V 1999 Perforin gene defects in familial hemophagocytic lymphohistiocytosis. Science 286:19571959.

5. Graham GE, Graham LM, Bridge PJ, Maclaren LD, Wolff JEA, Coppes MJ, Egeler RM 2000 Further evidence for genetic heterogeneity in familial hemophagocytic lymphohistiocytosis (FHLH). Pediatr Res 48:227-232

The Hospital for Sick Children

555 University Avenue

Toronto, Ontario

Canada M5G 1 X8 